\title{
Sulfabromomethazine Sodium
}

National Cancer Institute

\section{Source}

National Cancer Institute. Sulfabromomethazine Sodium. NCI Thesaurus. Code C84591.

A sodium salt form of sulfabromomethazine, a long-acting derivative of sulfamezathine that is used in the poultry, swine and cattle industries for the treatment of coccidiosis and various bacterial infections. 